\title{
Reflective Model of Brand Awareness on Repurchase Intention and Customer Satisfaction
}

\author{
Gunawan Bata ILYAS ${ }^{1}$, Sri RAHMI' ${ }^{2}$ Hasmin TAMSAH ${ }^{3}$, Abdul Razak MUNIR ${ }^{4}$, \\ Aditya Halim Perdana Kusuma PUTRA ${ }^{5}$
}

Received: July 03, 2020 Revised: July 25, 2020 Accepted: August 10, 2020

\begin{abstract}
This study aims to analyze and confirm brand awareness' role in influencing the repurchase intention both directly and indirectly on customer satisfaction variables and repurchase intention variables. The contribution brought by this study is to reflect manifest variables such as recall, purchase, and consumption. The number of respondents in this study was 200 samples using the online survey data collection method (Google form), while the research approach is quantitative explanatory. The data analysis test tools include the Structural Equation Modeling (SEM) approach with AMOS as a statistical data analysis software and Sobel test to indirectly test the relationship. This study consists of four hypotheses, of which three hypotheses are positively and significantly related (brand awareness on repurchase intention, brand awareness on customer satisfaction, and customer satisfaction on repurchase intention). Through indirect relationship, namely, brand awareness on repurchase intention through customer satisfaction, the study showed no significant effect. In a comprehensive way, this study emphasizes the factor of customer satisfaction as a determinant of consumer loyalty and repurchase intention. Therefore, creating optimal customer satisfaction, service excellence, promotion and massive advertising, guaranteeing the safety and ease-of-use apps, and ease of shopping, especially for e-commerce industry, is a serious concern.
\end{abstract}

Keywords: Brand Awareness, Customer Satisfaction, Repurchase Intention

JEL Classification Code: M30, M31, M11, M37

\section{Introduction}

The development of information technology is increasing, and so is Internet access technology, thus making Indonesia

${ }^{1}$ First Author and Corresponding Author. Associate Professor, Department of Management, STIE AMKOP, Makassar, Indonesia [Postal Address: Meranti Street No.1, Panakkukang, Makassar, South Sulawesi Province, 90231, Indonesia]

Email: gunawan.bata.ilyas72@gmail.com

${ }^{2}$ Associate Professor, Department of Management, STIE AMKOP, Makassar, Indonesia.

${ }^{3}$ Associate Professor, Department of Management, STIE AMKOP, Makassar, Indonesia.

${ }^{4}$ Associate Professor, Department of Management, Faculty of Economic \& Business, Universitas Hasanuddin, Makassar, Indonesia.

${ }^{5}$ Assistant Professor, Department of Management, Faculty of Economic \& Business, Universitas Muslim Indonesia, Makassar, Indonesia. Email: adityatrojhan@gmail.com

(c) Copyright: The Author(s)

This is an Open Access article distributed under the terms of the Creative Commons Attribution Non-Commercial License (https://creativecommons.org/licenses/by-nc/4.0/) which permits unrestricted non-commercial use, distribution, and reproduction in any medium, provided the original work is properly cited. the fourth-largest smartphone user market in the world (Machmud, 2018). In line with the survey by Roy Morgan Research, smartphone ownership in the world has doubled in a year, from $12 \%$ to $24 \%$; cell phone use rose $10 \%$ to $84 \%$ of the population. The number shows a positive trend, because the use of smartphones makes the Internet accessed very easily, quickly, and cheaply (Škařupová et al., 2016; Tsetsi \& Rains, 2017). The development of the world of technology has also affected the complete open access to shopping using online marketplace services or e-commerce (Mansur et al., 2019; Lestari et al., 2020). As per research from Google, Indonesia ranks first with $49 \%$ of the digital economy value in the Southeast Asian region (Permatasari \& Kartikowati, 2018). Therefore, it makes Indonesia an essential market for e-commerce companies and digital marketing startups (Oktaviani, 2017).

Digitalization marks the start of era of Industry 4.0. With the growth of technology and online culture, shopping patterns will shift to e-commerce systems (Mashur et al., 2019). The phenomenon of the number of stores operating indicates a shift in trading patterns toward the online system. The change from a conventional shopping system to an online marketplace will force any country to struggle 
with the effects of this digitalization because, if it doesn't, it won't get revenue potential or it will even experience severe economic failure. Indonesia is predicted to become one of the big players in the digital media world. Besides, three positive trends point to Indonesia becoming a large digital media user, namely, the increase in smartphone usage (Machmud, 2018), mobile marketing growth (Wirawan \& Oktivera, 2015), and e-commerce growth (Indahingwati et al., 2019).

Many benefits are obtained for the company if the transaction is done through e-commerce, such as low transaction costs (Reynolds, 2000), cheap advertising costs (Akash \& Mishra, 2015; Yang et al., 2016; Lawrence \& Tar, 2010), faster communication between sellers and buyers (Indahingwati et al., 2019; Benyoucef et al., 2001), simplifying the supply chain (Johnston \& Mak, 2000), minimizing transport requirements, reducing shipping costs, and reducing the need for selling space (Melnik \& Alm, 2002). The behavior of the current generation that tends to like online activities, including shopping or transacting on e-commerce platforms, is one of the main factors that support the high level of competition between online trading service provider applications (Indahingwati et al., 2019; Safia et al., 2019). Therefore, it is reasonable to think that shopping transactions with online shopping grow rapidly. In other e-commerce business opportunities, consumers are not only defined as buyers but also as website users (Kim et al., 2009).

An e-commerce application from South Korea, Shopee, shows remarkable development in a short period. Recorded from the first quartile (Q1) in 2017 to Q1 2019 Shopee continues to occupy the top of the most popular e-commerce competition in Southeast Asia as the most downloaded apps on Play Store (Praja et al., 2018). It is in competition with e-commerce in Indonesia, which is supported by unicorn and decacorn investors such as Alibaba, Tokopedia, Bukalapak, and Lazada. Shopee experienced a rapid increase in terms of the number of visitors and was able to face fierce competition. Through Snapcart Research conducted in January 2018 in Indonesia involving 6,123 respondents, as many as $37 \%$ of respondents shop using the Shopee application (Rosdiana et al., 2020). This survey also mentioned that Shopee excels with an awareness score of $81 \%$, beating other market players Lazada 80\% and Tokopedia 78\%. Even in 2019, based on the MarkPlus survey, Shopee became the most embedded brand of e-commerce in Indonesian women's minds (Masitoh et al., 2019; www.industry.co.id, 2019). Products that have a high level of brand awareness will influence consumer purchasing decisions (Lee et al., 2019; Mashur et al., 2020; Hoang et al., 2020).

The decision to shop on the e-commerce platform starts with the intention of the purchase. The consumer is involved in a series of information searches about the desired item on the various e-commerce options available. Then, that specific form of purchase intention becomes a purchase decision and leads to satisfaction and repurchase plan (Fang et al., 2014; Kim \& Yang, 2020; Khoa et al., 2020). At the stage of forming consumer purchase intention, positioning of brand awareness has an important role (Gerber et al., 2016). Ha and Perks (2005) states that consumers tend to buy a product that is well known and familiar. Objectively, this study aims to analyze the role of brand awareness in influencing repurchase intention both directly and indirectly on the variable of customer satisfaction and the variable repurchase intention. The novelty of this study is the use of variables such as recall, purchase, and consumption. Apart from that, this study is expected to have managerial implications for the main business actors in the field of e-commerce, as well as consequences for the development of the field of management marketing specifically, which is digital marketing.

\section{Literature Review and Hypothesis Development}

\subsection{Factors that Motivate the Use of E-Commerce}

E-commerce is the application of technology that leads to the automation of business transactions and workflows. Companies can, thus, be more efficient and effective in increasing profits. Businesses can utilize four types of e-commerce. The most straightforward kind is the consumerto-consumer business model (C-to-C), business-toconsumer (B-to-C), daily deals, and Marketplace consumerto-business-to-consumer (C-to-B-to-C). Marketplace (C-to-B-to-C) has excellent potential to grow the people's economy, which is the pillar of the national economy. Marketplace's strategic position is a place for local producers to exist in the era of digital markets. Like most emerging markets, Indonesia faces challenges with the adoption and implementation of new technology and rapid infrastructure development. Indonesian consumers are also becoming smarter, and increasingly know more natural ways to shop and choose brands in the online space.

Consumers are people who buy or use goods or services, while marketers are people who provide services (Firman et al., 2020). The most challenging question for marketers is why buyers make purchases or not. Such knowledge is essential for marketers because a strong understanding of buyer behavior will explain what is necessary to consumers and suggest important influences on consumers in decisionmaking (Kotler et al., 2010). The factors that influence consumer purchasing decisions are very complex. This is rooted in psychology and a little sociology from the buyer (Applebaum, 1951; Cernansky, 2018; Muruganantham \& 
Bhakat, 2013). The consumer decision-making process is influenced by many factors such as cultural, social, personal and psychological (Unal \& Aydın, 2013; Indahingwati et al., 2019; Nguyen et al., 2019). Cultural factors become the most pervasive and most influential on consumer behavior (Kim \& Song, 2010). In many cases, it represents trust. Consumer purchasing is a process that offers two useful perspectives: the decision-making process related to consumer purchasing and the factors that influence the purchasing process (Kotler et al., 2010). The consumer purchasing process can be divided into personal, psychological, social factors, and cultural factors. Social factors such as small groups of consumers, families, group references, roles, and social status can influence consumer responses and influence (Dittmar \& Drury, 2000). Personal factors include age, life-cycle stage, work, education, and economic situation. Psychological factors such as motivation, perception, learning, beliefs and personality attitudes also play a significant role in the consumer decision-making process (Duffett, 2015).

Several things could be factors that influence Indonesia's online shopping intentions. 1) The comfort factor fosters online shopping intentions. Duarte et al. (2018) mentioned that the ability to provide comfort to someone and facilitate routine needs is a factor of convenience. Duarte et al. (2018) and (García-Fernández et al., 2018) state that the level of comfort in conducting transactions is included in perceived support or Perceive Convenience. 2) The trust factor influences online shopping intentions (Andaleeb, 1996; Moriuchi \& Takahashi, 2016). Moriuchi and Takahashi (2016) state that one's confidence in the reliability and cost-efficiency incurred in carrying out an activity is a trust factor. Mistrust is also related to the level of integrity of the organizer (Sun \& Ding, 2020). 3) The risk factor affects online shopping intentions (Shaw \& Sergueeva, 2019). The risk aspect is also a barrier for someone to shop online, but is not ready to bear the risk of loss. Yang et al. (2020) define risk as something with an uncertain amount felt by consumers. Purchases that are not made directly, such as shopping through e-commerce, contain an element of significant risk for consumers. Mansur et al. (2019) state that the perception of loss related to time, security, financial, social and performance is a Perceive Risk factor. 4) The amount of effort affects the intention to shop online. E-commerce helps users with little push in the shopping process. This factor can be helpful for these users in finding the items needed. Mansur et al. (2019) state the level of ease-of-use of the system as a factor of expectation of ease or Effort Expectancy, namely, the hope that e-commerce can facilitate the work of users. The level of difficulty and ease-of-use of e-commerce are very influential on the user's decision to adopt e-commerce. 5) The habit factor affects online shopping intentions. The habit factor to do online shopping has not happened with new users so that someone may experience difficulties because they are not yet familiar. This is related to the difficulty factor because new users are not accustomed to doing the activity. Mansur et al (2019) states that the level of individual behavior to repeat an activity is called Habit. 6) The social influence influences online shopping intentions (Muruganantham \& Bhakat, 2013). This is a matter related to social factors where the social context influences to shop online. Regarding social influence factors, Yang et al. (2016) and Dwivedi et al. (2020) state that social influence impacts on the use of the system whereby using this system makes the user feel he has a better image, called Social Influence. Chen and Lin (2019) state that the level of individual perception of essential people's attitudes is a factor that is included in Social Influence.

\subsection{Brand Awareness, Customer Satisfaction, Repurchase Intention}

A brand is a name, condition, design, symbol, or anything that can be a tool to identify a product, product or service, and a differentiator between one seller and another seller. All around us, brand naming is inseparable from a unique and essential moment. For example, Google's name, which was born as a result of typing Larry Page's Googolplex, or Adobe, inspired by the name of the river (Adobe-Creek) that flows behind the house of founder John Warnock. The Apple brand was inspired by Steve Jobs' love for Isaac Newton. The birth of a brand is triggered intentionally or unintentionally. There are philosophical values attached to them (design, symbol, name, and so on). The essence of a brand is not only limited to introducing something to others, or to be known by others. More in-depth than that, the core of the brand illustrates the meaning of how sturdy a persistence is, how confident it is about Enduring Relevance, how capable the brand is to inspire, change or direct someone's behavior (providing direction) (Kusuma et al., 2020). In the concept of business and marketing, companies focus on building awareness for their consumers so that a brand can take root in the minds of consumers. Knowledge about a brand can lead to impulsiveness for some consumers (Foroudi et al., 2014).

Brand awareness has several levels starting from the lowest level, namely, not recognizing the brand and brand recognition, the top-of-the-mind recalling stage. Brand awareness can signify the existence, commitment, and core that are very important for a company. So, if the brand's knowledge is high, then the presence of the brand can always be felt. Several factors usually cause a brand to gain high brand awareness: advertised continuously, and associated with the existence and distribution of products that reach various groups (Foroudi et al., 2014; Mashur et al., 2020). 
A well-managed brand can engender customer satisfaction and customer value (Macdonald \& Sharp, 2000). Brand Awareness has several important indicators that are familiar (Ha \& Perks, 2005), such as gives a sense of satisfaction and pride (Aaker, 2010), is easily recognized (Balmer, 2001), and can influence buyer decisions (Mashur et al., 2019; Mashur et al., 2020). Brand awareness is the ability of a prospective buyer to recognize or recall that a brand is part of a particular product category. Rup et al. (2020) and Chaney et al. (2018) state that brand awareness is the ability of consumers to identify brands under different conditions reflected in brand reconstruction and recall performance.

Prior studies (e.g., Lu et al., 2014; Das, 2014; Dabbous $\&$ Barakat, 2020) show that brand awareness influences consumer decision-making for a product. The more wellknown a brand, the higher the possibility of the brand being the choice of consumers when making a purchase. Dabbous and Barakat (2020) state that brand awareness has become an important variable that influences consumer perceptions of a brand. So, it can be assumed that a well-known brand can also affect the desire to buy or use a product more than once (repurchase intention). Brand awareness also acts as a critical factor in consumer buying interest. Certain brands will try to master their minds to influence consumer interests making it a choice among various existing brand alternatives (Curina et al., 2020).

In the global economy and business environment where competition is fierce, organizations must be oriented toward consumers because otherwise, they could suffer fatal consequences (Firman et al., 2020). Only organizations that are consumer-oriented and can provide superior value to their customers alone will survive in the business arena where competition is fierce like now. Besides, satisfied consumers tend to be less influenced by competitors, less sensitive to prices, and are loyal longer. Kumar and Nayak (2018) and Grover et al. (2004) define customer satisfaction as a person's feelings of pleasure or disappointment that results from comparing the performance and product quality against the expected expectations. Producers are said to be able to provide satisfaction if the performance of services or products can meet consumer desires (Chong \& Rundus, 2004).

Customer satisfaction is the combined result of perception, evaluation, and psychological reactions to the experience gained from consuming goods or services. Thus, it can be said that joy is relative. The only thing that can measure satisfaction with a product is consumers who use or consume the product (Benoit et al., 2020). Fulfillment of aspects of customer satisfaction becomes an exciting dynamic for marketers because there are non-standardized expectations that must be met from every product that is marketed. It is from consumer satisfaction that an assessment of the product consumed will be formed, so that consumers can decide whether the product is suitable for consumption in the future. The perceived satisfaction of a product's performance can also make consumers recommend the product to others (Mashur et al., 2020). Thus, the intention to repurchase or repeatedly (repurchase intention) can also be done through other people. This is what guides researchers to use customer satisfaction as a mediator variable in this study.

Repurchase intention is the intention to repurchase a product twice or more (Filieri \& Lin, 2017; Won \& Kim, 2020). In reaching a level where consumers want to repurchase a product, it means that the company or product provider must meet consumer expectations. Satisfied consumers can make repeat purchases compared to dissatisfied consumers. Thus, repurchase intention is the desire of consumers to repurchase a product in the form of goods or services that have previously felt the benefits and quality. Departing from the subject of the literature review and the necessary background of the introduction, this study now provides an overview of the conceptual framework and hypotheses explained as in Figure 1.

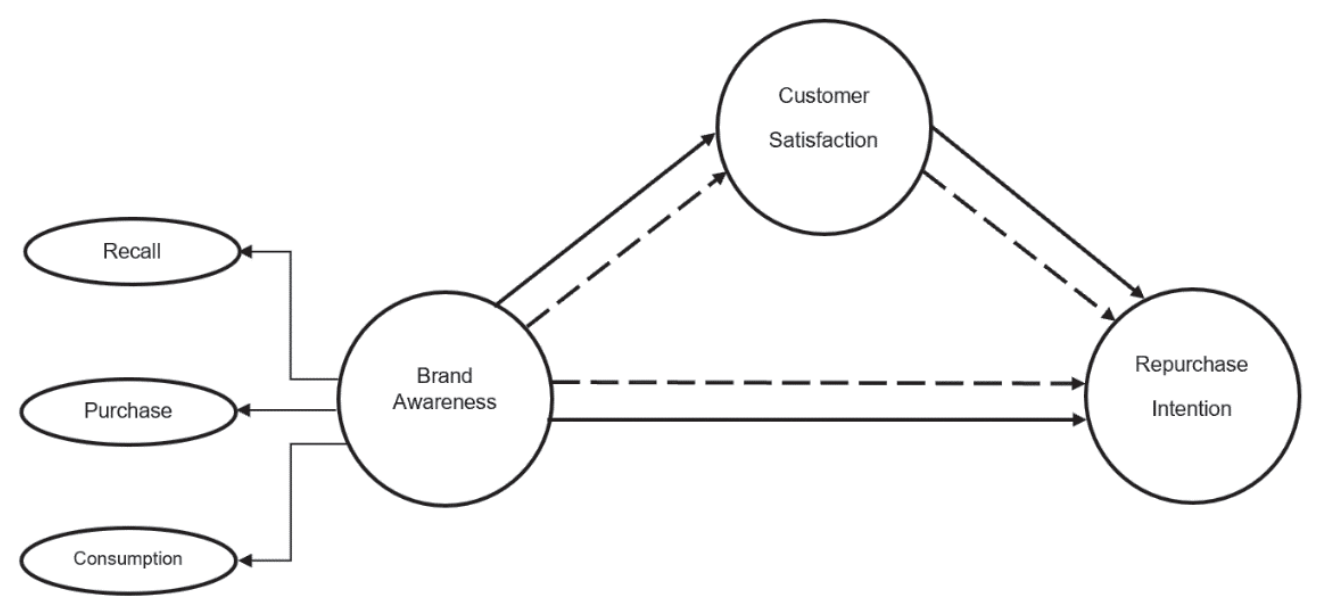

Figure 1: Conceptual Framework 
H1: Brand awareness has a positive and significant effect on repurchase intention

H2: Brand awareness has a positive and significant effect on customer satisfaction

H3: Customer satisfaction has a positive and significant effect on repurchase intention

H4: Brand awareness affects repurchase intention through customer satisfaction

\section{Research Methods and Materials}

In this study, there are three latent variables, namely, brand awareness, repurchase intention, and customer satisfaction as mediator variables. Each variable is measured by dimensions and indicators. Sinclair and Keller (2014) and Tong and Hawley (2009) posit that brand awareness consists of the recall dimension. The manifest variable 'brand awareness', i.e., brand recall consisting of questions assessing consumers' remembering the Shopee application as an e-commerce brand; the public easily recognizes the slogan that is a Shopee tagline; the color orange on the Shopee platform, the website and in the play store/AppStore application makes it easy for me to recognize it is a Shopee e-commerce application. The manifest variable 'repurchase intention', i.e., purchase consisting of questions that consumers will retain Shopee as a marketplace for shopping online; comfort and convenience factors make consumers decide to shop online at Shopee; factors of minimum risk and safety guarantees make consumers decide to shop online at Shopee. The manifest variable 'customer satisfaction', i.e., consumption consisting of Shopee application questions that assess priority choice applications for online shopping; massive advertising and promotion of Shopee makes one of the main reasons why I prefer Shopee over other e-commerce applications.

Furthermore, customer satisfaction variables consist of questions, i.e., excellent service guarantees shown by Shopee to customers are truly realized; the price of the products offered to consumers is highly competitive; items traded in the Shopee application are goods of original quality. The repurchase intention variable consists of questions, i.e., as a consumer I often use the Shopee application to shop online; there are not many negative testimonies that I receive from my social environment about Shopee, so it makes me even more sure to make Shopee a trusted online shopping application; in a month I use the Shopee application to shop more than twice. Measurement of items and variables use a 5-point Likert scale ( 1 = Strongly-Disagree; 2 = Disagree; $3=$ Neutral; $4=$ Agree; $5=$ Strongly-agree). Data collected via an online-questionnaires using Google forms that was distributed to 200 respondents in Makassar City, South Sulawesi Province, Indonesia.

The sampling method we refer to is the study of brand management that has been carried out by Mashur et al.
(2020) Rational reasons ground the determination of prior research (e.g., the similarity of research locations and data collection methods that both use online surveys). Previously, we distributed 400 questionnaires, but when testing data normality, valid data only came from 200 respondents. Data collected were analyzed using Structural Equation Model (SEM) analysis with the help of the Amos 21 application. In addition to measuring the magnitude of the influence of each dimension and indicator on latent variables and between latent variables with each other, this analysis model also aims to find Structural compatibility modeling with confirmatory factor analysis technique that is indicated by the value of meeting the standard of the goodness of fit. The last step in testing our data used Sobel test online statistics and hypothesis testing with probability criteria of 0.05 and a significance level of $<0.05$.

\section{Results and Discussion}

\subsection{Statistics Results}

Table 1 presents the descriptive research data. For the clustering of 200 respondents, the female respondent group was the largest $(55.5 \%)$, the largest age group were the 28 - 38 years old $(52 \%)$. $48 \%$ of respondents are employees. Finally, the dominant income clustering (47.5\%) comes from groups with income ranging between 1 and 5 million rupiahs per month. All respondents' answers on each measurement item are in the mean range of $3.7-4.2$ with a standard error value $<0.1$. After analyzing the data, the next step is testing the goodness of fit model. This study's model has passed through two stages of model feasibility testing, so that the data displayed on the results of this analysis are considered final and fit. As for the several stages of model testing that have not been feasible, we have released and re-calibrated to find the right model's feasibility. So, that the perfect and feasible model is presented in Figure 2. The results of the modification of this model indicate that the model is structurally appropriate as seen from the value of goodness of fit where CMIN / DF <2 is 1.626; GFI $>0.9,0.905$; TLI $>$ 0.9 which is 0.912 ; CFI $>0.9,0.940$; and RMSEA $>0.3<0.8$ which is 0.75 .

The results of the model feasibility output are shown in Table 2, which explains the results of the model modification. The results of data analysis showed that the model was structurally appropriate as seen from the value of goodness of fit where CMIN / DF <2 was 1.560; GFI > 0.9, 0.940; TLI $>0.9$ which is 0.912; CFI $>0.9,0.940$; and RMSEA> $0.3<0.8$ which is 0.75 . The manifest variable (i.e., recall, purchase, consumption) has a high construct reliability value above 0.60 , while each item forming variable manifest has a Cronbach's Alpha value above 0.70 . The significance value in testing the goodness fit of models is $1 \%$. 
Table 1: Data Descriptive

\begin{tabular}{|c|c|c|c|}
\hline Descriptive & \multicolumn{2}{|c|}{$\mathbf{N}$} & $\%$ \\
\hline $\begin{array}{l}\text { Gender } \\
\text { Men } \\
\text { Women }\end{array}$ & \multicolumn{2}{|c|}{$\begin{array}{c}89 \\
111\end{array}$} & $\begin{array}{l}44.5 \\
55.5\end{array}$ \\
\hline $\begin{array}{l}\text { Age (Years) } \\
18-25 \\
28-38 \\
38-48 \\
>48\end{array}$ & \multicolumn{2}{|c|}{$\begin{array}{c}77 \\
104 \\
12 \\
7\end{array}$} & $\begin{array}{c}38.5 \\
52 \\
6 \\
3.5\end{array}$ \\
\hline $\begin{array}{l}\text { Status } \\
\text { Student } \\
\text { Employee } \\
\text { Entrepreneur }\end{array}$ & \multicolumn{2}{|c|}{$\begin{array}{l}56 \\
96 \\
34\end{array}$} & $\begin{array}{l}28 \\
48 \\
17\end{array}$ \\
\hline $\begin{array}{l}\text { Income (in Rupiah) per } \\
\text { month } \\
<1 \text { million } \\
1-5 \text { million } \\
5-10 \text { million } \\
>10 \text { million }\end{array}$ & \multicolumn{2}{|c|}{$\begin{array}{l}42 \\
95 \\
43 \\
20\end{array}$} & $\begin{array}{c}21 \\
47.5 \\
21.5 \\
10\end{array}$ \\
\hline Item & Standard Error & Standard Deviation & Mean \\
\hline $\begin{array}{l}\text { RC1 } \\
\text { RC2 } \\
\text { RC3 } \\
\text { PC1 } \\
\text { PC2 } \\
\text { PC3 } \\
\text { CO1 } \\
\text { CO2 } \\
\text { CS1 } \\
\text { CS2 } \\
\text { CS3 } \\
\text { RI1 } \\
\text { RI2 } \\
\text { RI3 }\end{array}$ & $\begin{array}{l}.05827 \\
.06218 \\
.05604 \\
.06036 \\
.05843 \\
.05811 \\
.06075 \\
.06089 \\
.05901 \\
.05819 \\
.06053 \\
.06560 \\
.05815 \\
.05545\end{array}$ & $\begin{array}{l}.82401 \\
.87934 \\
.79254 \\
.85366 \\
.82631 \\
.82175 \\
.85911 \\
.86109 \\
.83454 \\
.82290 \\
.85602 \\
.92774 \\
.82241 \\
.78420\end{array}$ & $\begin{array}{l}4.1200 \\
3.7250 \\
3.9950 \\
3.9300 \\
4.0750 \\
4.0900 \\
3.9750 \\
3.9150 \\
4.0450 \\
3.9650 \\
4.0300 \\
3.9400 \\
4.0450 \\
4.0900\end{array}$ \\
\hline
\end{tabular}

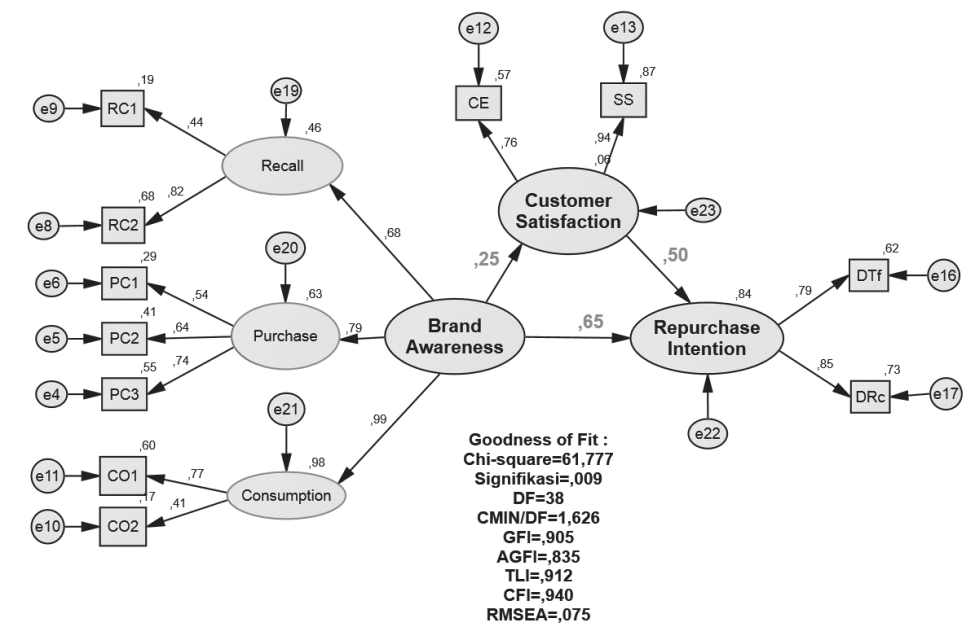

Figure 2: Statistics Result 
Table 2: Goodness of Fit Model

\begin{tabular}{|c|c|c|c|c|c|c|c|c|c|}
\hline & & & $\begin{array}{l}\text { Cronbach's } \\
\text { Alpha }\end{array}$ & $\begin{array}{l}\text { Construct } \\
\text { Reliability }\end{array}$ & $\begin{array}{l}\text { Standardized } \\
\text { Estimate }\end{array}$ & Estimate & $\begin{array}{c}\text { Standard } \\
\text { Error }\end{array}$ & $\begin{array}{l}\text { Critical } \\
\text { Ratio }\end{array}$ & $\mathbf{P}$ \\
\hline $\begin{array}{l}\text { Customer } \\
\text { Satisfaction }\end{array}$ & $\leftarrow$ & $\begin{array}{l}\text { Brand } \\
\text { Awareness }\end{array}$ & & & 0.379 & 0.383 & 0.316 & 2.808 & 0.005 \\
\hline Recall & $\leftarrow$ & $\begin{array}{l}\text { Brand } \\
\text { Awareness }\end{array}$ & & & 0.769 & 0.270 & 0.064 & 4.202 & 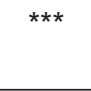 \\
\hline Purchase & $\leftarrow$ & $\begin{array}{l}\text { Brand } \\
\text { Awareness }\end{array}$ & & & 0.793 & 0.472 & 0.081 & 5.812 & $* * *$ \\
\hline Consumption & $\leftarrow$ & $\begin{array}{l}\text { Brand } \\
\text { Awareness }\end{array}$ & & & 0.953 & 0.327 & 0.083 & 3.940 & $* * *$ \\
\hline $\begin{array}{l}\text { Repurchase } \\
\text { Intention }\end{array}$ & $\leftarrow$ & $\begin{array}{l}\text { Customer } \\
\text { Satisfaction }\end{array}$ & & & 0.458 & 0.285 & 0.071 & 3.989 & $* * *$ \\
\hline $\begin{array}{l}\text { Repurchase } \\
\text { Intention }\end{array}$ & $\leftarrow$ & $\begin{array}{l}\text { Brand } \\
\text { Awareness }\end{array}$ & & & 0.700 & 0.439 & 0.089 & $4 / 941$ & $* * *$ \\
\hline Recall & & & & 0.605 & & & & & \\
\hline $\mathrm{RC} 3$ & $\leftarrow$ & Recall & 0.769 & & 0.516 & 1 & & & \\
\hline $\mathrm{RC} 2$ & $\leftarrow$ & Recall & 0.748 & & 0.696 & 1.379 & 0.411 & 3.357 & *** \\
\hline $\mathrm{RC} 1$ & $\leftarrow$ & Recall & 0.762 & & 0.567 & 0.883 & 0.203 & 4.101 & *** \\
\hline Purchase & & & & 0.683 & & & & & \\
\hline PC3 & $\leftarrow$ & Purchase & 0.750 & & 0.753 & 1 & & & \\
\hline PC2 & $\leftarrow$ & Purchase & 0.757 & & 0.625 & 0.723 & 0.142 & 5.095 & $* * *$ \\
\hline PC1 & $\leftarrow$ & Purchase & 0.761 & & 0.537 & 0.537 & 0.122 & 4.394 & $* * *$ \\
\hline Consumption & & & & 0.683 & & & & & \\
\hline $\mathrm{CO} 2$ & $\leftarrow$ & Consumption & 0.770 & & 0.445 & 1 & & & \\
\hline Co1 & $\leftarrow$ & Consumption & 0.753 & & 0.706 & 1.750 & 0.474 & 3.69 & $* * *$ \\
\hline Customer Sati & fact & & & 0.782 & & & & & \\
\hline CS1 & $\leftarrow$ & $\begin{array}{l}\text { Customer } \\
\text { Satisfaction }\end{array}$ & 0.884 & & 0.779 & 1 & & & \\
\hline $\mathrm{CS} 2$ & $\leftarrow$ & $\begin{array}{l}\text { Customer } \\
\text { Satisfaction }\end{array}$ & 0.881 & & 0.861 & 1.614 & 0.185 & 8.720 & $* \star \star$ \\
\hline cS3 & $\leftarrow$ & $\begin{array}{l}\text { Customer } \\
\text { Satisfaction }\end{array}$ & 0.889 & & 0.554 & 0.913 & 0.183 & 4.994 & $\star * \star *$ \\
\hline Repurchase In & tenti & & & 0.786 & & & & & \\
\hline RI1 & $\leftarrow$ & $\begin{array}{l}\text { Repurchase } \\
\text { Intention }\end{array}$ & 0.896 & & 0.602 & 1 & & & \\
\hline $\mathrm{RI} 2$ & $\leftarrow$ & $\begin{array}{l}\text { Repurchase } \\
\text { Intention }\end{array}$ & 0.879 & & 0.801 & 1.661 & 0.268 & 6.197 & $\star * *$ \\
\hline RI3 & $\leftarrow$ & $\begin{array}{l}\text { Repurchase } \\
\text { Intention }\end{array}$ & 0.879 & & 0.812 & 1.500 & 0.243 & 6.174 & $* * *$ \\
\hline
\end{tabular}

Note: ${ }^{* * *},{ }^{* *}$ and ${ }^{*}$ indicates significant at $1 \%, 5 \%$ and $10 \%$ level of significance based on t-statistics 
Table 3: Sobel Test and Hypothesis Result

\begin{tabular}{|l|c|c|c|c|c|c|c|c|c|}
\hline & Estimate & $\mathbf{S . E}$ & $\mathbf{a b}$ & $\mathbf{a}^{2}$ & $\mathbf{b}^{2}$ & $\mathbf{S E a}$ & $\mathbf{S E b}^{2}$ & $\mathbf{b}^{2} \mathbf{S E a}$ & $\mathbf{a}^{2} \mathbf{S E b}$ \\
\hline $\begin{array}{l}\text { Customer Satisfaction } \leftarrow \\
\text { Brand Awareness }\end{array}$ & 0.245 & 0.122 & 0.122446 & 0.060 & & 0.015 & & 0.004 & 0.001 \\
\hline $\begin{array}{l}\text { Repurchase Intention } \leftarrow \\
\text { Customer Satisfaction }\end{array}$ & 0.508 & 0.097 & & & 0.258 & & 0.009 & & \\
\hline \multicolumn{7}{|c|}{ Hypothesis Result } \\
\hline \multicolumn{7}{|c|}{ Path } & 0.648 & $<0.01$ & Supported \\
\hline Brand Awareness $\rightarrow$ Repurchase Intention & 0.245 & 0.044 & Supported \\
\hline Brand Awareness $\rightarrow$ Customer Satisfaction & 0.508 & $<0.01$ & Supported \\
\hline Customer Satisfaction $\rightarrow$ Repurchase Intention & 0.126 & 0.06 & Not Supported \\
\hline $\begin{array}{l}\text { Brand Awareness } \rightarrow \text { Customer Satisfaction } \rightarrow \text { Repurchase } \\
\text { Intention }\end{array}$ &
\end{tabular}

In addition to the direct relationship of brand awareness to repurchase intention, AMOS's output also shows that the influence of brand awareness on repurchase intention, if mediated by customer satisfaction (standardized indirect effect), is 0.126 . To determine whether customer satisfaction in this study mediates the relationship between brand awareness and repurchase intention, the researcher uses the Sobel test, which is illustrated in Table 3. The Sobel test produced a $\mathrm{z}$-value of 1.875 , smaller than the z-table value in the normal distribution of $1.96(\mathrm{sig}=0.05)$. It means that, although customer satisfaction mediates the relationship between brand awareness and repurchase intention, the role is not significant. The next step is testing the hypothesis, explained in Table 2.

Four hypotheses have been previously proposed in the literature review section. Three of them have a positive and significant effect (e.g., brand awareness on repurchase intention, brand awareness on customer satisfaction, customer satisfaction on repurchase intention). But the relationship of variables that state brand awareness on repurchase intention by making the customer satisfaction variable an interveningvariable states there is no definite and significant effect.

\subsection{Discussion}

Brand awareness is a fundamental factor that determines the quality of a brand. The presence of a brand must be introduced intensively and massively to ensure that brand awareness is embedded in the minds of the public and potential consumers at large. In achieving excellence by enhancing brand awareness value, the study has shown that several indicators can be used as references such as brand recall, where the ease of remembering a brand is such an essential factor (e.g., color, slogan, tagline, jargon). Realizing brand recall as a trigger for brand awareness can be achieved through massive advertising on various platforms such as $\mathrm{TV}$, YouTube, or even through sponsoring various events (music, sports, or others). Based on the results of this study, we found that the majority of respondents know the Shopee marketplace from the YouTube channel or advertisements featured on their social media. Then, the massive community using the Shopee application is also a trigger to make Shopee a priority choice. Most people in Indonesia shop online in this marketplace. It is easy for people to know Shopee only through jargon and tagline; the determination and selection of colors on the website are also easily recognized by consumers.

No less important than brand recall, the factor that also determines why most communities make Shopee their priority choice for online shopping are the comfort, convenience, and security factors during the transaction and shopping process. The variety of payment methods makes consumers decide to shop on the Shopee application. While collecting data, we observed that the offer of free shipping to all parts of Indonesia became a critical variable why Shopee was looked up by consumers. Besides, Shopee's guarantees of a safe delivery process of premium quality goods is also an essential reason for consumers choose to shop online with the company. The safety factor and convenience in shopping are set out comprehensively as a form of service excellent Shopee supplies to its consumers. To every customercomplaints, Shopee will respond quickly to make consumers feel safe and comfortable. Therefore, these various reasons push consumers to give positive testimonials on the Shopee application; satisfaction in carrying out transactions online makes consumers feel satisfied. In the future, if consumers want to go back shopping, then Shopee becomes their first choice (re-purchase).

Theoretical implication: This study generally confirms that the various determinant factors in consumer purchasing 
decisions are triggered through shopping experiences or transactions, both personally or derived from the testimonies of others. Customer satisfaction factors determine customer loyalty and re-purchasing or re-consuming of products or services. Based on consumer satisfaction, several strategies have been developed or implemented by many producers. In this study, we highlight that service-excellent strategies, massive promotions, security guarantees, and ease of transactions make Shopee platforms increase in brand awareness and brand-value size. Previous studies complement this study in confirming that customer satisfaction mediates the repeated decisions of consumer purchases (re-purchasing). The main trigger to increase customer satisfaction lies in optimal brand awareness and positive testimonials.

Managerial implication: This study pays particular attention to the use of brand-awareness improvement strategies through the optimization of massive advertising on various marketing channels. So, this study provides practical input, especially for digital marketing practitioners, to imitate the implementation of advertising promotion activities carried out by Shopee. Procedurally, this study also has implications, not only for digital marketing practitioners, but also for learners in the field of marketing management science, that factors to increase brand awareness in terms of value and size are the main concerns that should be prioritized. The optimal strategy and the regular measurement of indicators of customer satisfaction become the power to determine business strategies in digital marketing.

\section{Conclusion}

From the results of this study, it can be concluded that first, branding is an essential strategy in marketing, especially in e-commerce business. A strategy that requires a considerable investment value, but offers long-term benefits, if done with policies with the right measurements. The success of embedding a brand in consumers' memories will result in repeated consumption of the brand. Consumers still use Shopee as their first online shopping choice due to positive testimonials from the environment or because they have been satisfied with previous transactions. Finally, satisfaction has a positive effect, but does not significantly affect repurchase. It can be assumed that realizing the customer satisfaction must be the primary target. The non-significance of indirect relationship can be assumed that the competitive factor within the same business activities as Shopee will lead people to transact on competitive online platforms. So, that it is essential for Shopee to keep working hard in carrying out new strategies to highlight the characteristics of the Shopee application further so that brand-awareness value is increasingly embedded in the minds of the public.

\section{References}

Aaker, D. (2010). Editorial: Marketing challenges in the next decade. Journal of Brand Management, 17(5), 315-316. https:// doi.org/10.1057/bm.2010.2

Akash, V., \& Mishra, K. (2015). E-commerce: an analytical study of online business transactions and its role in promotion of rural entrepreneurship in India. International Journal of Research in Social Sciences, 5(2), 185-201.

Andaleeb, S. S. (1996). An experimental investigation of satisfaction and commitment in marketing channels: The role of trust and dependence. Journal of Retailing, 72(1), 77-93. https://doi.org/10.1016/S0022-4359(96)90006-8

Applebaum, W. (1951). Studying customer behavior in retail stores. Journal of Marketing, 16(2), 172-179. https://doi. org/10.2307/1247625

Balmer, J. M. T. (2001). Corporate identity, corporate branding and corporate marketing-Seeing through the fog. European Journal of Marketing, 35(3), 248-291. https://doi. org/10.1108/03090560110694763

Benoit, S., Kienzler, M., \& Kowalkowski, C. (2020). Intuitive pricing by independent store managers: Challenging beliefs and practices. Journal of Business Research, 115(April), 70-84. https://doi.org/10.1016/j.jbusres.2020.04.027

Benyoucef, M., Alj, H., Vézeau, M., \& Keller, R. K. (2001). Combined negotiations in e-commerce: Concepts and architecture. Electronic Commerce Research, 1(3), 277-299. https://doi.org/10.1023/A:1011598105857

Cernansky, R. (2018). Millennials spending more money eating out, less time preparing food at home. Retrieved July 17, 2020 from: https://www.supermarketnews.com/consumer-trends/ millennials-spending-more-money-eating-out-less-timepreparing-food-home

Chaney, I., Hosany, S., Wu, M.-S. S., Chen, C.-H. S., \& Nguyen, B. (2018). Size does matter: Effects of in-game advertising stimuli on brand recall and brand recognition. Computers in Human Behavior, 86(September), 311-318. https://doi.org/10.1016/j. chb.2018.05.007

Chen, S.-C., \& Lin, C.-P. (2019). Understanding the effect of social media marketing activities: The mediation of social identification, perceived value, and satisfaction. Technological Forecasting and Social Change, 140(March), 22-32. https:// doi.org/10.1016/j.techfore.2018.11.025

Chong, V. K., \& Rundus, M. J. (2004). Total quality management, market competition and organizational performance. The British Accounting Review, 36(2), 155-172. https://doi.org/10.1016/j. bar.2003.10.006

Curina, I., Francioni, B., Hegner, S. M., \& Cioppi, M. (2020). Brand hate and non-repurchase intention: A service context perspective in a cross-channel setting. Journal of Retailing and Consumer Services, 54(May), 102031. https://doi. org/10.1016/j.jretconser.2019.102031 
Dabbous, A., \& Barakat, K. A. (2020). Bridging the online offline gap: Assessing the impact of brands' social network content quality on brand awareness and purchase intention. Journal of Retailing and Consumer Services, 53(March), 101966. https:// doi.org/10.1016/j.jretconser.2019.101966

Das, G. (2014). Linkages of retailer awareness, retailer association, retailer perceived quality and retailer loyalty with purchase intention: A study of Indian food retail brands. Journal of Retailing and Consumer Services, 21(3), 284-292. https://doi. org/10.1016/j.jretconser.2014.02.005

Dittmar, H., \& Drury, J. (2000). Self-image - is it in the bag? A qualitative comparison between "ordinary" and "excessive" consumers. Journal of Economic Psychology, 21(2), 109-142. https://doi.org/10.1016/S0167-4870(99)00039-2

Duarte, P., Costa e Silva, S., \& Ferreira, M. B. (2018). How convenient is it? Delivering online shopping convenience to enhance customer satisfaction and encourage e-WOM. Journal of Retailing and Consumer Services, 44(September), 161-169. https://doi.org/10.1016/j.jretconser.2018.06.007

Duffett, R. G. (2015). Facebook advertising's influence on intention-to-purchase and purchase amongst millennials. Internet Research, 25(4), 498-526. https://doi.org/10.1108/ IntR-01-2014-0020

Dwivedi, Y. K., Ismagilova, E., Hughes, D. L., Carlson, J., Filieri, R., Jacobson, J., Jain, V., Karjaluoto, H., Kefi, H., Krishen, A. S., Kumar, V., Rahman, M. M., Raman, R., Rauschnabel, P. A., Rowley, J., Salo, J., Tran, G. A., \& Wang, Y. (2020). Setting the future of digital and social media marketing research: Perspectives and research propositions. International Journal of Information Management, 102168. [In Press]. https://doi. org/10.1016/j.ijinfomgt.2020.102168

Fang, Y., Qureshi, I., Sun, H., McCole, P., Ramsey, E., \& Lim, K. H. (2014). Trust, satisfaction, and online repurchase intention. MIS Quarterly, 38(2), 407-A9. https://doi.org/10.25300/ MISQ/2014/38.2.04

Filieri, R., \& Lin, Z. (2017). The role of aesthetic, cultural, utilitarian and branding factors in young Chinese consumers' repurchase intention of smartphone brands. Computers in Human Behavior, 67(February), 139-150. https://doi.org/10.1016/j. chb.2016.09.057

Firman, A., Putra, A. H. P. K., Mustapa, Z., Ilyas, G. B., \& Karim, K. (2020). Re-conceptualization of Business Model for Marketing Nowadays: Theory and Implications. Journal of Asian Finance, Economics and Business, 7(7), 279-291. https:// doi.org/10.13106/jafeb.2020.vol7.no7.279

Foroudi, P., Melewar, T. C., \& Gupta, S. (2014). Linking corporate logo, corporate image, and reputation: An examination of consumer perceptions in the financial setting. Journal of Business Research, 67(11), 2269-2281. https://doi. org/10.1016/j.jbusres.2014.06.015

García-Fernández, J., Gálvez-Ruíz, P., Fernández-Gavira, J., VélezColón, L., Pitts, B., \& Bernal-García, A. (2018). The effects of service convenience and perceived quality on perceived value, satisfaction and loyalty in low-cost fitness centers. Sport
Management Review, 21(3), 250-262. https://doi.org/10.1016/j. smr.2017.07.003

Gerber, C., Ward, S., \& Goedhals-Gerber, L. (2016). The Impact of Perceived Risk on on-Line Purchase Behaviour. Risk Governance and Control: Financial Markets \& Institutions, 4(4), 13-18. https://doi.org/10.22495/rgcv4i4clart4

Grover, S., Agrawal, V. P., \& Khan. (2004). A digraph approach to TQM evaluation of an industry. International Journal of Production Research, 42(19), 4031-4053. https://doi.org/10.10 80/00207540410001704032

Ha, H., \& Perks, H. (2005). Effects of consumer perceptions of brand experience on the web: Brand familiarity, satisfaction and brand trust. Journal of Consumer Behaviour: An International Research Review, 4(6), 438-452. https://doi.org/10.1002/cb.29

Hoang, X. L., Nguyen, T. K. C., Ly, H. M., Luong, T. T., \& Nguyen, T. T. Q. (2020). The Moderating Role of CSR Associations on the Link between Brand Awareness and Purchase Intention. Journal of Asian Finance, Economics and Business, 7(6), 233240. https://doi.org/10.13106/jafeb.2020.vol7.no6.233

Indahingwati, A., Launtu, A., Tamsah, H., Firman, A., Putra, A. H. P. K., \& Aswari, A. (2019). How Digital Technology Driven Millennial Consumer Behaviour in Indonesia. Journal of Distribution Science, 17(8), 25-34. http://dx.doi.org/10.15722/ jds.17.08.201908.25

Johnston, R. B., \& Mak, H. C. (2000). An emerging vision of Internet-enabled supply-chain electronic commerce. International Journal of Electronic Commerce, 4(4), 43-59. https://doi.org/10.1080/10864415.2000.11518378

Khoa, B. T., Nguyen, T. D., \& Nguyen, V. T.-T. (2020). Factors affecting Customer Relationship and the Repurchase Intention of Designed Fashion Products. The Journal of Distribution Science, 18(2), 17-28. https://doi.org/10.15722/ jds.18.2.20202.17

Kim, H.-B., Kim, T. T., \& Shin, S. W. (2009). Modeling roles of subjective norms and eTrust in customers' acceptance of airline B2C eCommerce websites. Tourism Management, 30(2), 266277. https://doi.org/10.1016/j.tourman.2008.07.001

Kim,H., \& Song, J. (2010). The quality of word-of-mouth in the online shopping mall. Journal of Research in Interactive Marketing, 4(4), 376-390. https://doi.org/10.1108/17505931011092844

Kim, Y. E., \& Yang, H. C. (2020). The Effects of Perceived Satisfaction Level of High-Involvement Product Choice Attribute of Millennial Generation on Repurchase Intention: Moderating Effect of Gender Difference. Journal of Asian Finance, Economics and Business, 7(1), 131-140. https://doi. org/10.13106/jafeb.2020.vol7.no1.131

Kotler, P., Armstrong, G., \& Philip Kotler, G. A. (2010). Principles of Marketing (4th ed.). Hoboken, NJ: Pearson Education.

Kumar, J., \& Nayak, J. K. (2018). Brand community relationships transitioning into brand relationships: Mediating and moderating mechanisms. Journal of Retailing and Consumer Services, 45(January), 64-73. https://doi.org/10.1016/j. jretconser.2018.08.007 
Kusuma, A. H. P., Sudirman, A., Purnomo, A., Aisyah, S., Sahir, S. H., Rumondang, A., Salmiah, S., Halim, F., Wirapraja, A., \& Napitupulu, D. (2020). Brand Management: Essence, Position and Strategy (pp. 1-194). Jakarta, Indonesia: Yayasan Kita Menulis. [Indonesian]

Lawrence, J. E., \& Tar, U. A. (2010). Barriers to e-commerce in developing countries. Information, Society and Justice Journal, $3(1), 23-35$.

Lee, J. E., Goh, M. L., \& Noor, M. N. B. (2019). Understanding purchase intention of university students towards skin care products. PSU Research Review, 3(3), 161-178. https://doi. org/10.1108/prr-11-2018-0031

Lestari, S. D., Leon, F. M., Widyastuti, S., Brabo, N. A., \& Putra, A. H. P. K. (2020). Antecedents and Consequences of Innovation and Business Strategy on Performance and Competitive Advantage of SMEs. Journal of Asian Finance, Economics and Business, 7(6), 365-378. https://doi.org/10.13106/jafeb.2020. vol7.no6.365

Lu, L. C., Chang, W. P., \& Chang, H. H. (2014). Consumer attitudes toward blogger's sponsored recommendations and purchase intention: The effect of sponsorship type, product type, and brand awareness. Computers in Human Behavior, 34(May), 258-266. https://doi.org/10.1016/j.chb.2014.02.007

Macdonald, E. K., \& Sharp, B. M. (2000). Brand awareness effects on consumer decision making for a common, repeat purchase product: A replication. Journal of Business Research, 48(1), 5-15. https://doi.org/10.1016/S0148-2963(98)00070-8

Machmud, K. (2018). The Smartphone Use in Indonesian Schools: The High School Students' Perspectives. Journal of Arts and Humanities, 7(2), 33-40. https://doi.org/10.18533/journal. v7i3.1354

Mansur, D. M., Sule, E. T., Kartini, D., Oesman, Y. M., Putra, A. H. P. K., \& Chamidah, N. (2019). Moderating of the role of technology theory to the existence of consumer behavior on e-commerce. Journal of Distribution Science, 17(7), 15-25. https://doi.org/10.15722/jds.17.07.201907.15

Mashur, R, Gunawan, B. I., Fitriany, Ashoer, M., Hidayat, M., \& Aditya, H. P. K. P. (2019). Moving from traditional to society 5.0: Case study by online transportation business. Journal of Distribution Science, 17(9), 93-102. https://doi.org/10.15722/ jds.17.09.201909.93

Masitoh, M. R., Wibowo, H. A., \& Ikhsan, K. (2019). Influence of Service Quality, Customer Satisfaction, and Brand Trust on Customer Loyalty in Shopee Mobile Application Users. Sains Manajemen, 5(1). https://doi.org/10.21776/ ub.profit.2019.013.02.8

Melnik, M. I., \& Alm, J. (2002). Does a seller's ecommerce reputation matter? Evidence from eBay auctions. The Journal of Industrial Economics, 50(3), 337-349.

Moriuchi, E., \& Takahashi, I. (2016). Satisfaction trust and loyalty of repeat online consumer within the Japanese online supermarket trade. Australasian Marketing Journal, 24(2), 146-156. https://doi.org/10.1016/j.ausmj.2016.02.006
Muruganantham, G., \& Bhakat, R. S. (2013). A Review of Impulse Buying Behavior. International Journal of Marketing Studies, 5(3), 149-160. https://doi.org/10.5539/ijms.v5n3p149

Nguyen, P. N. D., Nguyen, V. T., \& Vo, N. N. T. (2019). Key Determinants of Repurchase Intention toward Organic Cosmetics. Journal of Asian Finance, Economics and Business, 6(3), 205-214. https://doi.org/10.13106/jafeb.2019.vol6. no3.205

Oktaviani, R. F. (2017). Mapping the Condition of SMEs in Indonesia in Adopting Ecommerce. International Journal of Pure and Applied Mathematics, 117(15), 973-982.

Permatasari, A., \& Kartikowati, M. (2018). The influence of website design on customer online trust and perceived risk towards purchase intention: a case of $\mathrm{O} 2 \mathrm{O}$ commerce in Indonesia. International Journal of Business and Globalisation, 21(1), 74-86. https://doi.org/10.1504/IJBG.2018.10015258

Praja, C. B. E., Setiyo, M., \& Lutfiyati, H. (2018). Temanggung Local Coffee Marketing Potential Through Marketplace: Tokopedia, Bukalapak, Shopee, Which Is The Best?. Journal of Community Services and Engagement, 1(1), 39-47.

Reynolds, J. (2000). eCommerce: a critical review. International Journal of Retail \& Distribution Management, 28(10), 417-444. https://doi.org/10.1108/09590550010349253

Rosdiana, E. V. A., Suharno, H., \& Kulsum, U. M. I. (2020). Effect of Price, Product Diversity, and Purchase Interest on Purchasing Decisions in Shopee Online Stores. Ekonomi Bisnis, 24(2), $13-23$.

Rup, J., Goodman, S., \& Hammond, D. (2020). Cannabis advertising, promotion and branding: Differences in consumer exposure between 'legal' and 'illegal' markets in Canada and the US. Preventive Medicine, 133(January), 106013. https:// doi.org/10.1016/j.ypmed.2020.106013

Safia, A., Chai, J., Frimpong, A. N. K., \& Akram, U. (2019). The impact of social media characteristics on e-commerce use behaviour among youth in developing countries. International Journal of Information Systems and Change Management, 11(2), 188-207. https://doi.org/10.1504/IJISCM.2019.10026376

Shaw, N., \& Sergueeva, K. (2019). The non-monetary benefits of mobile commerce: Extending UTAUT2 with perceived value. International Journal of Information Management, 45(April), 44-55. https://doi.org/10.1016/j.ijinfomgt.2018.10.024

Sinclair, R. N., \& Keller, L. (2014). A case for brands as assets: Acquired and internally developed. Journal of Brand Management, 21(4), 286-302. https://doi.org/10.1057/ bm. 2014.8

Škařupová, K., Ólafsson, K., \& Blinka, L. (2016). The effect of smartphone use on trends in European adolescents' excessive Internet use. Behaviour \& Information Technology, 35(1), 68-74. https://doi.org/10.1080/0144929X.2015.1114144

Sun, W., \& Ding, Y. (2020). Corporate social responsibility and cash flow volatility: The curvilinear moderation of marketing capability. Journal of Business Research, 116(August), 48-59. https://doi.org/10.1016/j.jbusres.2020.05.016 
Tong, X., \& Hawley, J. M. (2009). Measuring customer-based brand equity: Empirical evidence from the sportswear market in China. Journal of Product \& Brand Management, 18(4), 262-271. https://doi.org/10.1108/10610420910972783

Tsetsi, E., \& Rains, S. A. (2017). Smartphone Internet access and use: Extending the digital divide and usage gap. Mobile Media \& Communication, 5(3), 239-255. https://doi. org/10.1177/2050157917708329

Unal, S., \& Aydın, H. (2013). An Investigation on the Evaluation of the Factors Affecting Brand Love. Procedia - Social and Behavioral Sciences, 92(October), 76-85. https://doi. org/10.1016/j.sbspro.2013.08.640

Wirawan, F. A. W., \& Oktivera, E. (2015). Analysis on the implementation of digital marketing towards motorbike transport service case study: GO-JEK (online taxi motorbike) Jakarta, Indonesia. 2015 International Conference on Information Technology Systems and Innovation (ICITSI), (pp.1-6).
Won, J., \& Kim, B.-Y. (2020). The Effect of Consumer Motivations on Purchase Intention of Online Fashion - Sharing Platform. Journal of Asian Finance, Economics and Business, 7(6), 197-207. https://doi.org/10.13106/jafeb.2020.vol7.no6.197

www.industry.co.id. (2019). Riset MarkPlus: Shopee Jadi Top of Mind Brand e-Commerce.... Online Magazine. Retrieved July 14, 2020 from: https://bit.ly/3hgoNvR

Yang, J., Sarathy, R., \& Lee, J. (2016). The effect of product review balance and volume on online Shoppers' risk perception and purchase intention. Decision Support Systems, 89(September), 66-76. https://doi.org/10.1016/j.dss.2016.06.009

Yang, Y., Gong, Y., Land, L. P. W., \& Chesney, T. (2020). Understanding the effects of physical experience and information integration on consumer use of online to offline commerce. International Journal of Information Management, 51(April), 102046. https://doi.org/10.1016/j.ijinfomgt.2019.102046 